translated into a sense that steps taken now to fend off that happening will be more economical than the steps it will be necessary to take at a later stage if a decision is delayed. Nuclear power engineers now being put out of work may comfort themselves that there will soon come a time when the world is crying out for their successors. It is not beyond the bounds of possibility that some of them will be employed in building fast reactors.

\section{Patents for eugenics}

\section{Eugenics is both unpopular and widely practised; will it} never contribute to the human condition?

EUGENICS has a bad name, but is the practice of this supposed black art as despicable as commonly supposed? The origins of the bad name are mostly historical and largely, but not exclusively, to do with Adolf Hitler. His position, unforgivable and unforgiven, was simple: many people (Jews, Gypsies, the congenitally disabled and even miscellaneous critics) are genetically undesirable and, for that reason, should be done away with. The other side of that coin, the goal of excavating from a whole people's genetic endowment the embodiment of a 'pure' and inherently 'superior' race of human beings was known, even in the 1930 s, to be genetically unattainable and replete with the disastrous potential of allowing a whole repertoire of recessive genes to come into their own. Even on the basis of the little then known about the working of the human genome, that argument was part of the liberal counterattack on the English eugenics movement of Edwardian times.

Hitler has now been thoroughly repudiated, especially in Germany (the criminality and noisiness of neo-Nazis notwithstanding). But has the repudiation been too thorough? That question now arises in an arcane form, in relation to a patent application submitted to the European Patent Office (EPO) on behalf of researchers at the University of Pennsylvania who have outlined a technique for arranging that the mammalian testis should be able produce only genetically engineered spermatozoa. In brief, the scheme would go beyond the essays in gene therapy now being attempted, and which are aimed exclusively at correcting congenital errors of metabolism by altering the genetic constitution of somatic cells in the individuals affected. Instead, it would manipulate the germ line of affected animals. A groundswell of opinion is building up that the EPO should refuse the application on the grounds that it offends against the rubric in EPO's charter that forbids patents for inventions that offend against "morality and public order".

This has all the makings of a splendid irrelevance. In the first place, the technique outlined is evidently aimed at the production of domesticated animals with desired genetic properties; the authors say that they included human beings only for completeness. Second, it is more a scheme than a tried technique, and may not qualify for protection on those grounds. Third, it is unthinkable that any human family, however anxious to rid itself of some unwanted version of a gene, would think of subjecting any one of its males to such a procedure when the risk of misplacing the gene in the genome must be very great - and the risk of doing more harm than good to offspring must be very high. And finally, it should not be part of the function of the EPO (although legally it is) to adjudicate on matters of morality and public order.

But what will happen when it is possible confidently and safely to manipulate genes in the cells of the human germ line? And should not the first patent application in the field be rejected so as to discourage those who will later seek protection for germ-line manipulation that could be safely used for human eugenics? That is how the argument goes, but it is inapplicable for several reasons. The least of them is that even the existing techniques of amniocentesis followed by abortion in the circumstances allowed by law constitutes eugenics of a mild sort; the offspring of those born after screening for an unwanted allele can be sure that they will not inherit that allele from the parent concerned. That may not be a means of changing the genetic constitution of a whole population quickly or decisively, but it is a eugenic procedure that greatly assists (and is welcomed by) many modern parents. Democratic governments, which cannot compel putative parents to take advantage of these techniques, also have a responsibility to encourage their use. Why should it draw a line (and where) between that familiar practice and germ-line manipulation if it could be safely practised?

The second and more important reason why EPO should resist the pressure to which it is now being exposed is that there is already national legislation (and the prospect of a European directive) where its writ runs that prevents genetic manipulation except under licence. If it took ten years (in the United States) to get the first somatic-cell gene therapy under way, how much longer will be the debates in the regulatory committees about proposals for the manipulation of germline cells and the organs in which they lie? And since the grant of a patent does not exempt its holder from the structure of national laws, what sense does it make to saddle EPO (and national patent offices in Europe) with responsibility for deciding moral questions that properly rest with national parliaments?

Arcane though its present origins may be, the question of whether techniques for manipulating the human germ line should be patentable is an important one. As things stand, there is no technique that can be safely used, whence the standard response of geneticists in the field, "We will never touch it!" But that would have been the response of most professional people half a century ago to the prospect, now a welcome reality, of amniocyntetic screening (or even the genetic diagnosis of blastocysts). Can one be sure that germline manipulation can never be safe? Or that, if and when it is, putative parents of that future generation will shrink from it as energetically as they do now? In the circumstances, open-mindedness is the most valuable asset, but those who call themselves "ethicists" should bend their minds to the definition of the circumstances in which national eugenic policies conflict with the rights of people to be individuals. That, of course, will turn out to be an enquiry not in genetics, but into prejudice, of which there is too much. 